\title{
Penetrating thoracic injuries - treatment of two patients after suicide attempts
}

\author{
Krzysztof Greberski ${ }^{1}$, Paweł Bugajski ${ }^{1}$, Stanisław Rzymski², Radosław Jarząbek ${ }^{1}$, Bogumił Olczak ${ }^{2}$, \\ Ryszard Kalawski ${ }^{1}$ \\ ${ }^{1}$ Multidisciplinary Municipal Hospital, Department of Cardiac Surgery, Poznan University \\ of Medical Sciences, Poznan, Poland \\ ${ }^{2}$ Multidisciplinary Municipal Hospital, Intensive Care Unit, Poznan, Poland
}

Kardiochirurgia i Torakochirurgia Polska 2015; 12 (1): 62-64

\begin{abstract}
Thoracic injuries are usually caused by penetrating or blunt trauma. The primary method of treatment is surgery. This study describes two cases of male patients with stab wounds of the chest resulting from suicide attempts. The first case involved a 29-year-old patient transported and admitted to the hospital with a knife still in his chest; its blade extended from the jugular notch to the $5^{\text {th }}$ thoracic vertebra but did not damage any important structures. The applied treatment, limited to evacuating the knife, resulted in a satisfactory outcome, and the patient was discharged from the intensive care unit (ICU) in good condition. The second patient reached the hospital on his own. On admission, he did not reveal the real cause of the wound; however, in view of his deteriorating condition, he admitted that the knife penetrated deeply into the mediastinum. In this case, sternotomy was necessary to stop the bleeding of the pulmonary trunk and internal thoracic artery. After completion of treatment, the patient was discharged in good condition. The described management of life-threatening situations conducted by a multidisciplinary team of consultants enabled the choice of optimal treatment methods and resulted in successful outcomes.
\end{abstract}

Key words: stab wounds, suicide, cardiac tamponade.

\section{Introduction}

Thoracic injuries are most commonly caused by penetrating trauma (stab or gunshot wounds) [1] or blunt trauma (traffic accidents, falls from heights) [2, 3]. The primary method of treatment in such cases is surgery preceded by diagnostic examinations [4]. This paper presents two cases of penetrating chest wounds treated at the Cardiac Surgery Department, Trauma Surgery Department, and Intensive Care Unit of the Józef Struś Multidisciplinary Hospital in Poznań. The patients were two young men, aged 29 and 36, who were admitted to the Trauma Center in 2013 after sui-

\section{Streszczenie}

Rany klatki piersiowej powstają najczęściej na skutek obrażeń penetrujących lub tępych. Podstawowym sposobem terapii jest leczenie operacyjne. W pracy opisano 2 przypadki ran kłutych klatki piersiowej. Leczeniu poddano mężczyzn po próbach samobójczych. Pierwszy opis dotyczy 29-letniego pacjenta przywiezionego do szpitala z wciąż tkwiącym w klatce piersiowej nożem, który nie uszkodził ważnych struktur, mimo że penetrował śródpiersie aż do wyrostka poprzecznego lewego kręgu Th5. Postępowanie ograniczone do ewakuacji narzędzia pozwoliło uzyskać dobry efekt i wypisać pacjenta w stanie dobrym z oddziału intensywnej opieki medycznej (OIOM). W drugim przypadku pacjent samodzielnie przybył do szpitala; pierwotnie nie ujawnił powodu rany klatki piersiowej, ale w obliczu pogarszającego się stanu zgłosił głębokie wniknięcie noża do śródpiersia. W tym przypadku konieczna była sternotomia i zaopatrzenie krwawiących struktur: pnia płucnego i tętnicy piersiowej wewnętrznej. Po zakończonym leczeniu pacjenta w stanie dobrym wypisano z OIOM. Postępowanie w opisanych sytuacjach bezpośredniego zagrożenia życia wypracowane przez multidyscyplinarny zespół konsultantów jednostki pozwoliło wybrać najlepszą metodę leczenia i zakończyć terapię sukcesem.

Słowa kluczowe: rany kłute, tamponada, samobójstwo.

cide attempts. The strategy for managing these life-threatening situations, designed by a multidisciplinary team of consultants, enabled the choice of optimal treatment and diagnostic methods for both patients.

\section{Case 1}

The 29-year-old patient had been undergoing psychiatric treatment for several years; his mental condition deteriorated, as evidenced by increasing aggression and significant psychomotor agitation. The patient's housemate decided 
that it was necessary to call the police and emergency services. During the ensuing negotiations with police officers, the patient stabbed himself in the chest above the sternum with a knife. He was admitted to the Emergency Department with a penetrating chest wound located at the level of the jugular notch (Fig. 1). At the time of admission, the patient was conscious and did not suffer from circulatory or respiratory failure (blood pressure 130/80, heart rate 90 bpm); his speech was coherent, but he had trouble swallowing. Imaging diagnostic procedures were started immediately, including a chest X-ray examination (Fig. 2) and computed tomography of the chest and neck. Initial evaluation revealed left-sided pneumothorax and injury of the left thyroid gland lobe; the blade of the knife extended from the jugular notch to the left transverse process of the Th5 vertebra without passing through important structures. Therefore, the patient was transferred to the operating theater, where, under general anesthesia and under the supervision of a cardiac surgery consultant, suction drainage was introduced to the left pleural cavity, and the knife was removed from the puncture site. As there was no significant bleeding or air leakage, the wound was cleaned and closed with surgical sutures (Ethilon 4/0). After the procedure, the patient was transferred to the intensive care unit (ICU), where analgosedation and mechanical ventilation were continued. During the $1^{\text {st }}$ day after the intervention, the patient was in a stable circulatory and respiratory condition with periodic drops of saturation to $90 \%$. In the afternoon, the drainage of red fluid from the left pleural cavity increased. Due to increasing symptoms of respiratory failure, a decision was made to employ mechanical ventilation and sedation. Computed tomography of the chest visualized a massive hematoma in the left pleural cavity; no contrast extravasation was observed; the distal segment of the drain had no contact with the hematoma. Furthermore, the examination revealed slight right-sided pneumothorax with fluid accumulation; the left lung was compressed by the hematoma, and edema was visualized on the left thyroid gland lobe. In light of these findings, a trauma surgeon was consulted; the surgeon decided to introduce another drain into the left pleural cavity, but found no indications for thoracotomy. On the next day, chest X-ray examination demonstrated that the amount of fluid in the left pleural cavity was reduced, the left lung was aerated, and the drains were properly located. Over the subsequent postoperative days, the patient's clinical condition stabilized, and he was extubated on the $8^{\text {th }}$ day. On the $10^{\text {th }}$ day after the removal of the pleural drains, the patient was transferred to the Regional Hospital for Nervous and Mental Diseases in Gniezno in a stable circulatory and respiratory condition.

\section{Case 2}

The 36-year-old patient without previous psychiatric history stabbed himself with a knife in the left side of the precordial area during an argument with his fiancée. The patient came to the hospital on his own; during admission, he claimed that the wound was superficial because it occurred while performing everyday kitchen chores. During his stay at the Emergency Department, cardiac surgical consultation and imaging examinations were recommended. During the consultation, the hemodynamic condition of the patient deteriorated. In view of the worsening clinical condition, the patient admitted that the wound was self-inflicted and potentially deep. Chest $X$-ray examination revealed an increase in the width of the mediastinal shadow on the left side; the urgently performed computed tomography of the chest revealed signs of bleeding into the mediastinum as well as atelectatic changes in the dorsal region of the left lung. Injury of the left brachiocephalic vein was also suspected. The patient was urgently transferred to the operating theater of the Cardiac Surgery Department.

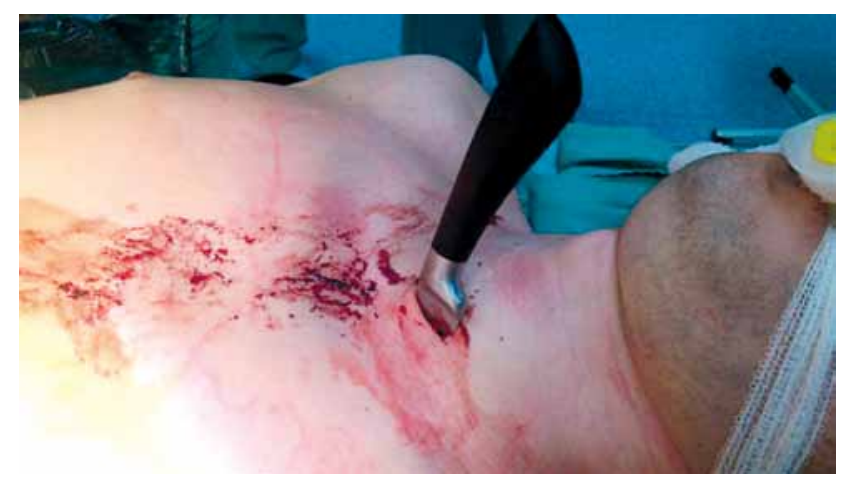

Fig. 1. The knife penetrating the patient's chest at the level of the jugular notch

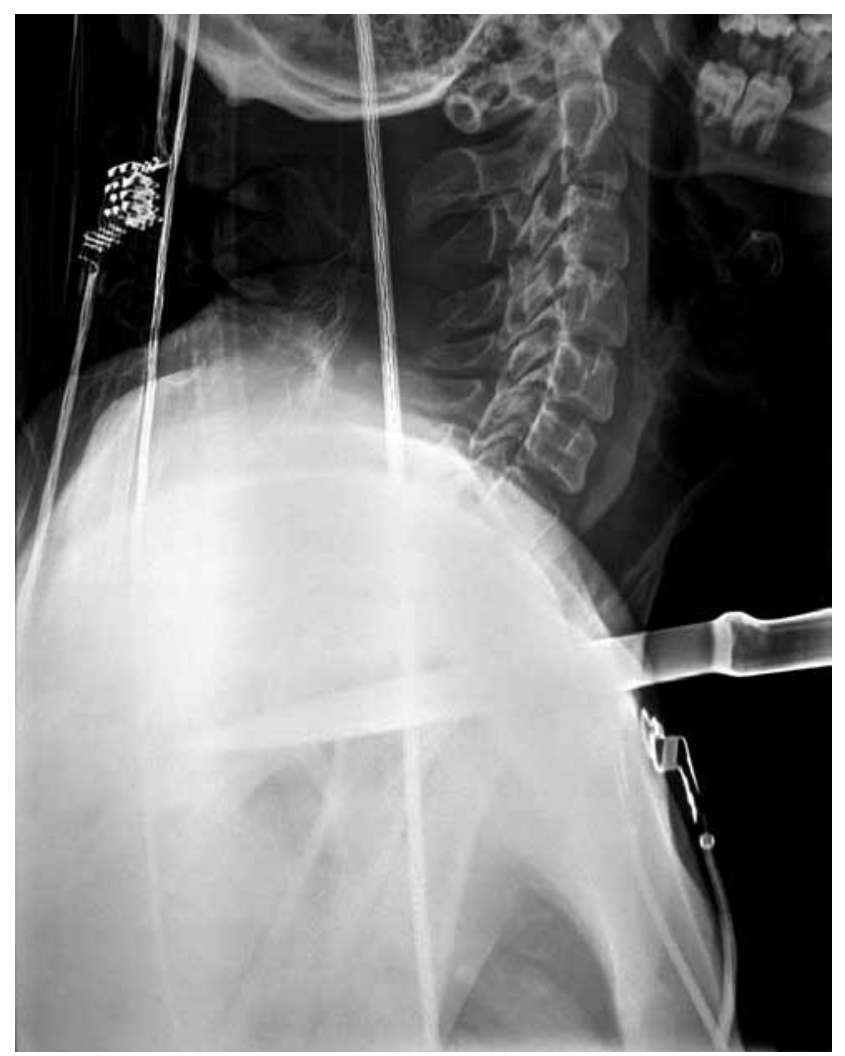

Fig. 2. Lateral photograph of the chest. The blade of the knife extending from the jugular notch to the left transverse process of the fifth thoracic vertebra (Th5) 


\section{Description of the procedure}

After median sternotomy was performed, a massive mediastinal hematoma was visualized. Dissection of the pericardial sac revealed a large amount of fluid blood and isolated thrombi causing cardiac tamponade. An incised wound, $2 \mathrm{~cm}$ in length, was observed on the anterior surface of the pulmonary trunk; it was immediately repaired with continuous Prolene 4-0 sutures. Evaluation of the pleural cavity demonstrated no lung damage or bleeding; however, injury of the interior chest wall and rupture of the left internal thoracic artery were observed. The massively bleeding stumps of the vessel were closed with metal clips. Active drainage of the mediastinum and pleural cavities was employed. The patient was transferred to the ICU in a relatively severe general condition (no coherent speech, mechanical ventilation, intravenous catecholamine infusion). For 4 days after the procedure, the patient required intensive medical care, catecholamine support, mechanical ventilation, and blood product transfusion. During the patient's stay at the ICU, his condition stabilized gradually, and he was extubated on the $5^{\text {th }}$ postoperative day. During subsequent days, the patient remained in a stable hemodynamic and respiratory condition. Suction drainage was removed on the $7^{\text {th }}$ postoperative day. Thanks to intensive rehabilitation, the conscious patient was transferred to the Trauma Surgery Department on the $10^{\text {th }}$ postoperative day in a stable circulatory condition in order to undergo further treatment.

\section{Conclusions}

The presented cases of young men with penetrating chest wounds confirm that all patients with thoracic inju- ries require intensive and individualized diagnostics and therapy. The applied multi-specialist approach resulted in successful outcomes. In the first case, the circumstances of the injury (visible handle of the knife which was almost completely sunk into the patient's chest) initially suggested that extensive surgical intervention would be required. However, the use of imaging diagnostics enabled the exclusion of serious injuries within the chest; the treatment could, therefore, be limited to removing the knife in the operating theater. In the case of the second patient, the small size of the penetrating chest wound did not reflect the extent of the damage caused by the blade. Computed tomography revealed serious injuries within the chest, which were promptly treated with cardiac surgery. Thoracic injuries should always be approached with the utmost caution, and advanced diagnostics should be employed as soon as possible in order to confirm or exclude damage to vital organs.

\section{Disclosure}

Authors report no conflict of interest.

\section{References}

1. Machała W, Brzozowski R, Mayers R, Rupenthal K. Rana postrzałowa szyi - analiza postępowania we wczesnym okresie szpitalnym. Anestezjologia i Ratownictwo 2012; 6: 276-286.

2. Bosman A, de Jong MB, Debeij J, van den Broek PJ, Schipper IB. Systematic review and meta-analysis of antibiotic prophylaxis to prevent infections from chest drains in blunt and penetrating thoracic injuries. Br I Surg 2012; 99: 506-513.

3. Zieren HU, Müller JM, Pichlmaier H, Rehm KE. Penetrating thoracic injuries. Unfallchirurgie 1992; 18: 191-196.

4. Kemper AR, Kennedy EA, McNally C, Manoogian SJ, Stitzel JD, Duma SM. Reducing chest injuries in automobile collisions: rib fracture timing and implications for thoracic injury criteria. Ann Biomed Eng 2011; 39: 2141-2151. 